\title{
A Correlative Study on Hepatitis C Virus Load Determined by Real Time Polymerase Chain Reaction with Serum Biomarkers in Patients with Renal Disease
}

\author{
Bagyalakshmi R¹, Malathi J'1, Prathiba $\mathbf{K}^{1}$, Samson $\mathbf{Y}^{1}$, Ravichandran $\mathbf{R}^{2}$ and Madhavan $\mathrm{HN}^{1 *}$
}

${ }^{1}$ Larsen and Toubro Microbiology Research Centre, Vision research Foundation, No 41, College Road, Sankara Nethralaya, Chennai 600006 ${ }^{2}$ Nephrology unit, MIOT Hospital, No. 4/112,Mount Poonamallee Road, Manapakkam Chennai-600089

\begin{abstract}
Purpose: To determine the Hepatitis $\mathrm{C}$ virus (HCV) load in peripheral blood specimens of patients with renal abnormality reporting to the nephrology unit and to correlate the viral load with different biomarkers in serum.

Materials and Methods: Fifty peripheral blood specimens were obtained from patients reporting to the nephrology unit and these patients were categorized into three groups as Group I: Renal Transplant patients, Group II: Dialysis patients, Group III: Other patients. with elevated liver enzymes and renal pathology. Peripheral blood specimens collected from kidney transplant recipients $(n=11)$, dialysis $(n=17)$ and others $(n=22)$ were subjected to detection of antibodies to HCV, determination of viral load by Real Time PCR and biochemical profiling consisting of estimation of bilirubin, total protein, alanine aminotransferase, and alkaline phosphatase. Antibodies to HCV were detected by ELISCAN ${ }^{\top M}$ HCV and the viral load by using HCV RG RTPCR kit (QIAGEN, Hilden). Statistical analysis - T test and the logistic regression analysis assessing the correlation between viral load and serum bilirubin, Serum glutamate pyruvate transaminase (SGPT), Alkaline phosphatase, total protein were performed using SPSS software version 14.0
\end{abstract}

Results: Antibodies to HCV were detected by ELISA in 39 (78\%) peripheral blood samples and genomic HCV was detected in $31(62 \%)$ by RTPCR. In 8 (16\%) patients, HCV antibodies only were detected and RTPCR did not reveal the presence of $\mathrm{HCV}$ in these specimens. Logistic regression analysis performed on biochemical parameters and viral load revealed correlation between alkaline phosphatase enzyme levels and viral load (Hosmer and Lemehow test $P$ value $<0.05$ statistically significant).

Conclusion: Determination of viral load is a reliable diagnostic test in detection of HCV infection. Elevated levels of alkaline phosphatase enzyme could be associated with increased viral load. To the best of our knowledge, this finding is the first being reported in Indian literature.

Keywords: HCV; Alkaline phosphatase; RTPCR.

\section{Introduction}

Hepatitis C virus (HCV) is a major cause of parenterally transmitted acute hepatitis [1]. HCV infection is a common cause of chronic liver disease that can lead to end-stage liver disease, including hepatocellular carcinoma [2-4]. Chronic HCV infection is often silent, and clinical symptoms are absent or minimal unless the disease is severe or cirrhosis is diagnosed. In chronically infected individuals, viral load, genotype, and elevated serum alanine aminotransferase (ALT) or serum glutamate pyruvate transferase (SGPT) levels may have clinical relevance [5-7]. When parenchymal liver cells are damaged, aminotransferases leak from the liver into the blood, resulting in elevated levels of aminotransferases and alkaline phosphatases. Usually, the viral load at 6 months is considered as a marker of remission $[8,9]$.

Dialysis patients remain a high-risk group for HCV infection [10]. Routine diagnosis of HCV is based on detection of anti-HCV antibody. However, due to the absence of an efficient in vitro culture system for $\mathrm{HCV}$ or assays capable of detecting viral antigens, direct detection of HCV has depended on nucleic acid amplification technology (NAT) techniques. Indeed, serological assays for detecting anti-HCV antibody cannot distinguish between patients with active infection and those who have cleared the virus [11]. NAT tests are based on nucleic acid amplification (PCR and transcription- mediated amplification) $[12,13]$ or signal amplification (branched-chain DNA assay) and are currently used to detect viremia [14].
Several researchers have developed Reverse Transcriptase based Real Time PCR [15-24], assays for detection and quantitation of HCV RNA. A relationship has been suggested between HCV type, subtype, and serum HCV RNA levels [6]. However, there are conflicting reports on the relationship between the biochemical markers of inflammation ALT, histological degree of inflammation, and serum HCV-RNA levels by reverse transcription (RT)-PCR. These conflicting results may relate to the heterogeneity of the patient groups studied. Patient groupings are often of mixed gender and ethnic origin, with ill-defined duration of disease, and mixed HCV genotype/subtype. In individuals with chronic hepatitis C, viral load and elevated serum ALT levels may have clinical relevance. ALT is most concentrated in liver and released into the bloodstream as the result of liver injury. It, therefore, serves

${ }^{*}$ Corresponding author: Dr. H.N.Madhavan, MD, Ph D, FAMS, FIC Path, President, Vision Research Foundation Director \& Professor of Microbiology L \& T Microbiology Research Centre, Sankara Nethralaya 41, College Road, Chennai - 600 006, India, Tel - 9144 28220709; Fax - 91442825 4180; E-mail: drhnm@snmail.org

Received July 08, 2011; Accepted March 03, 2012; Published March 08, 2012

Citation: Bagyalakshmi R, Malathi J, Prathiba K, Samson Y, Ravichandran R, et al. (2012) A Correlative Study on Hepatitis C Virus Load Determined by Real Time Polymerase Chain Reaction with Serum Biomarkers in Patients with Renal Disease. J Mol Biomark Diagn 3:123. doi:10.4172/2155-9929.1000123

Copyright: (c) 2012 Bagyalakshmi R, et al. This is an open-access article distributed under the terms of the Creative Commons Attribution License, which permits unrestricted use, distribution, and reproduction in any medium, provided the original author and source are credited 
Citation: Bagyalakshmi R, Malathi J, Prathiba K, Samson Y, Ravichandran R, et al. (2012) A Correlative Study on Hepatitis C Virus Load Determined by Real Time Polymerase Chain Reaction with Serum Biomarkers in Patients with Renal Disease. J Mol Biomark Diagn 3:123. doi:10.4172/2155-9929.1000123

Page 2 of 5

as a fairly specific indicator of liver status [25].The present study was undertaken to investigate the HCV viral load and its association with biochemical profile in patients with renal abnormality.

\section{Materials and Methods}

Patients and clinical specimens: The present study was approved by Ethics Committee of both the Research Institutes and informed consent was obtained from the patients who were enrolled in the study. The study subjects were categorized into three groups as Group I: Renal Transplant patients, Group II: Dialysis patients, Group III: Other patients. Fifty peripheral blood specimens collected from kidney transplant recipients $(\mathrm{n}=11)$, dialysis patients $(\mathrm{n}=17)$ and others with renal pathology $(\mathrm{n}$ =22) were subjected to detection of antibodies to HCV, Real Time PCR and serum biomarker study consisting of estimation of bilirubin, total protein, alanine aminotransferase, and alkaline phosphatase. Antibodies to HCV were detected by using a third generation ELISA kit ELISCAN ${ }^{\mathrm{TM}}$ HCV. Viral load was estimated by using HCV RG RTPCR kit (QIAGEN, Hilden).

RNA extraction: RNA was extracted from the peripheral blood specimens using RNA extraction kit (QIAGEN, Germany) according to the manufacturer's instructions. In brief, $280 \mu \mathrm{l}$ of QIAGEN lysis buffer (AVL) was pipette into the bottom of a $1.5 \mathrm{ml}$ microfuge tube (DEPC treated) and $2.8 \mu \mathrm{l}$ of carrier RNA was added. To this, $70 \mu \mathrm{l}$ of the clinical specimen was added to the microfuge tube and mixed by pulse vortexing for 15 seconds. The specimen was incubated at room temperature for 15 minutes. $280 \mu \mathrm{l}$ of ethanol (96-100\%) was added to the sample and mixed by gentle pipetting for 15 seconds. The mixture was carefully applied to the QIAamp mini spin column (in a $2 \mathrm{ml}$ collecting tube) without wetting the rim and centrifuged at $8000 \mathrm{rpm}$ for 1 minute. The QIAamp mini spin column was placed in a clean 2 $\mathrm{ml}$ collecting tube and the tube containing the filtrate was discarded. $500 \mu \mathrm{l}$ of buffer AW1 was added and centrifuged at $8000 \mathrm{rpm}$ for 1 minute. After discarding the filtrate, $500 \mu \mathrm{l}$ of buffer AW2 was added without wetting the rim and centrifuged at 14,000 rpm for 3 minutes. For elution, $50 \mu \mathrm{l}$ of buffer AVE was added and incubated at room temperature for 1 minute, followed by centrifugation at 8,000 rpm for 1 minute The eluted RNA was used to determine the viral load.

Determination of viral load: The viral load was estimated in the peripheral blood specimens using a commercial kit. The artus HCV RG RT-PCR kit was used for the detection of HCV RNA using polymerase chain reaction on Rotor Gene Q (QIAGEN, Hilden, Germany). The amplification reaction was carried out following the manufacturer's instructions. Reverse transcription was carried out $50^{\circ} \mathrm{C}$ for 30 minutes followed by initial denaturation at $95^{\circ} \mathrm{C}$ for 15 minutes followed by 50 cycles of initial denaturation at $95^{\circ} \mathrm{C}$ for 30 seconds, annealing at $50^{\circ} \mathrm{C}$ for 60 seconds and extension at $72^{\circ} \mathrm{C}$ for 30 seconds. The viral load was expressed in $\mathrm{IU} / \mathrm{ml}$

Inte rpretation of viral load: $\mathrm{HCV}$ viral load was interpreted according to the guidelines published online by Hepatitis Central, 2011 (www.hepatitiscentral.com). Viral load is interpretated as very low : below 200,000 IU/ml, low: 200,000 to 1,000,000 IU/ml, Medium : $1,000,000$ to $5,000,000 \mathrm{IU} / \mathrm{ml}$, high: $5,000,000$ to $25,000,000$ and very high: above 25,000,000.

Statistical methods: Standard deviation, mean and Logistic regression analysis comparing the correlation between viral load and serum bilirubin, SGPT, Alkaline phosphatase, total protein were calculated using SPSS software version 14.0.

\section{Results}

Antibodies to HCV were detected in 39 (78\%) out of 50 peripheral blood samples. Genomic HCV was detected in 31 (62\%) by Reverse Transcriptase based Real Time PCR. HCV antibodies were detected in 8 (16\%) patients by ELISA but HCV RNA was not detected by RTPCR The comparative analysis of detection of HCV RNA among different groups is provided in Table 1.

The distribution of viral load in Group I: renal transplant, Group II: Dialysis patients and Group 3: Others with elevated liver enzymes an d renal pathology is provided in Figure 1, 2 and 3 respectively.

Group I: Renal transplant patients $(\mathrm{n}=9)$, a very high viral load was estimated in $1(11.11 \%)$ specimen, medium viral load in $6(66.66 \%)$ specimens and a very low viral load in $2(22.22 \%)$ specimens. In Group II: Dialysis patients $(\mathrm{n}=10)$, a very high viral load was estimated in $1(10 \%)$ specimen, high viral load in $2(20 \%)$ specimens, medium viral load in $3(30 \%)$ specimens, low viral load in $1(10 \%)$ specimen and a very low viral load in $3(30 \%)$ specimens. In Group III : Other patients with elevated liver enzymes and abnormal renal pathology $(n=12)$, a high viral load was estimated in $1(8.33 \%)$ specimen, a medium viral load in $2(16.66 \%)$ specimens and a very low viral load in $9(75 \%)$ specimens.

The statistical analysis (mean and standard deviation) performed on serum biomarkers in both HCV RNA positive and HCV RNA negative group using $\mathrm{T}$ test is provided in Table 2 and the logistic regression analysis calculated using Hosmer and Lemehow test is provided in Table 3.

A logistic regression analysis was performed on the biomarkers -SGPT, Serum bilirubin, Total protein, alkaline phosphatase and albumin with HCV viral load. The biomarker alkaline phosphatase levels was found to have a correlation with HCV viral load ( $P$ value $<$ 0.05 statistically significant) and all the other biomarkers were found to have no correlation or statistical significance.

\section{Discussion}

Hepatitis $\mathrm{C}$ virus (HCV) infection is a major cause of liver disease that is characterized by the presence of antibodies against $\mathrm{HCV}$ proteins (i.e., anti-HCV antibodies) and HCV RNA in serum. During acute HCV infection, $15-20 \%$ of individuals clear the virus, with loss of serum HCV RNA and normalization of liver- function test results. In the present study HCV antibody alone (HCV RNA not detected) was

\begin{tabular}{|l|l|l|}
\hline Groups & $\begin{array}{l}\text { Genomic HCV } \\
\text { Detected* } \\
\mathbf{N}=\mathbf{3 1}\end{array}$ & $\begin{array}{l}\text { Genomic HCV } \\
\text { not detected } \\
\mathbf{N}=19\end{array}$ \\
\hline $\begin{array}{l}\text { Group I : } \\
\text { Renal Transplant } \\
\mathrm{N}=11\end{array}$ & $9(81.81 \%)$ & $2(18.18 \%)^{@}$ \\
\hline $\begin{array}{l}\text { Group II : Dialysis } \\
\mathrm{N}=17\end{array}$ & $10(58.82 \%)$ & $7(41.17 \%)^{\#}$ \\
\hline $\begin{array}{l}\text { Group III : Others } \\
\mathrm{N}=22\end{array}$ & $12(54.54 \%)$ & $10(45.45 \%)^{\star *}$ \\
\hline
\end{tabular}

Note:

*Antibodies to HCV was detected by third generation ELISA kit in all the 31 specimens in which viral load was detected

\#HCV antibodies alone were detected by ELISA in one serum sample obtained from a renal transplant patient

$@$ HCV antibodies alone were detected by ELISA in three serum samples obtained from dialysis patients

${ }^{* *} \mathrm{HCV}$ antibodies alone were detected by ELISA in four samples obtained from patients with elevated liver enzymes and renal pathology

Table 1: Comparative analysis of detection of HCV RNA among different groups. 
Citation: Bagyalakshmi R, Malathi J, Prathiba K, Samson Y, Ravichandran R, et al. (2012) A Correlative Study on Hepatitis C Virus Load Determined by Real Time Polymerase Chain Reaction with Serum Biomarkers in Patients with Renal Disease. J Mol Biomark Diagn 3:123. doi:10.4172/2155-9929.1000123

Page 3 of 5

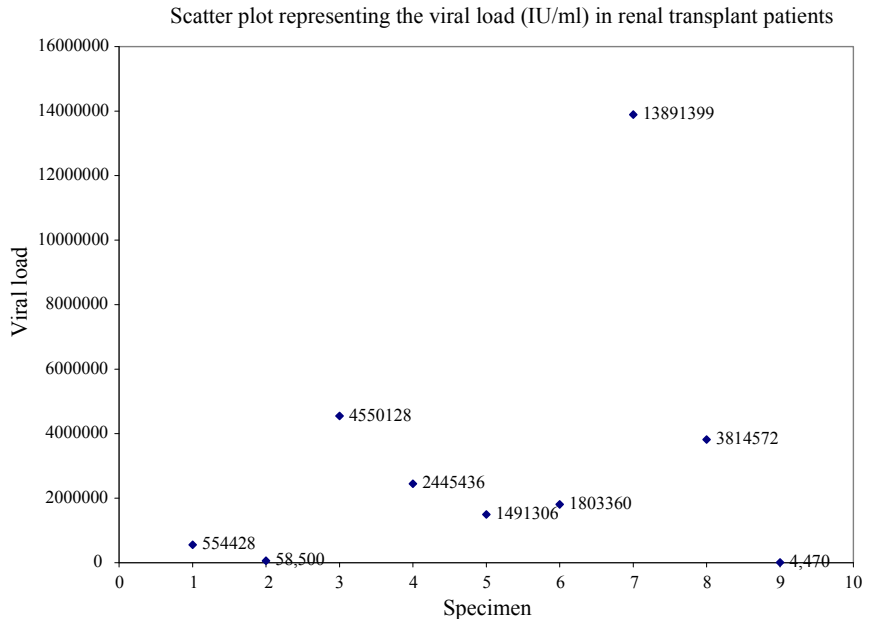

Figure 1: Scatter plot representing the viral load (IU/ml) in Renal transplant patients (Group I: $n=9$ )

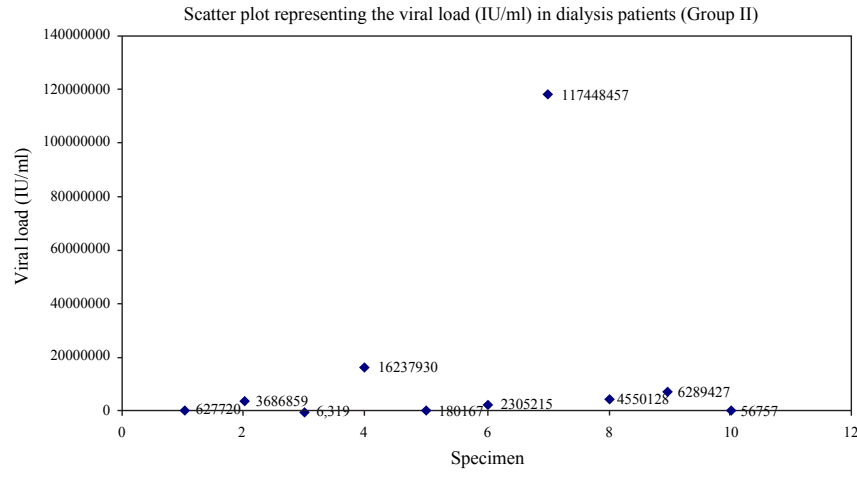

Figure 2: Scatter plot representing the viral load (IU/ml) in dialysis patients (Group II: $n=10$ ).

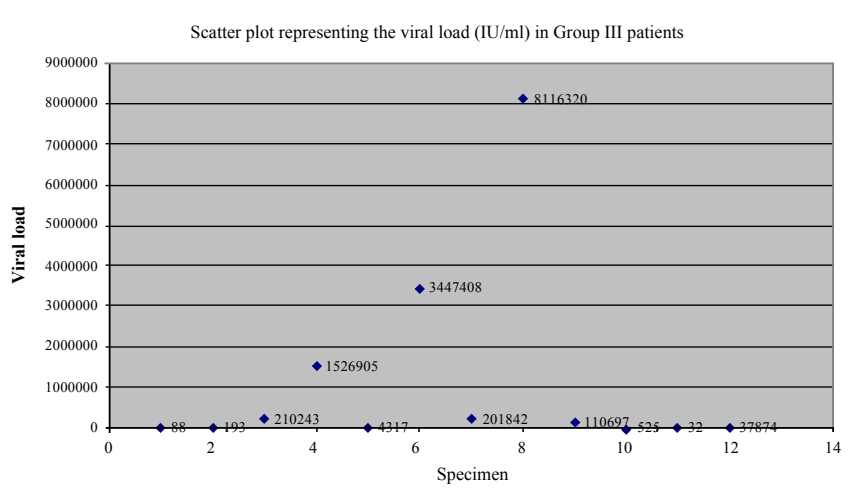

Figure 3: Scatter plot representing the viral load $(\mathrm{IU} / \mathrm{ml})$ in other group of patients (Group III: $n=12$ ).

detected in $16 \%$. This could be due to the clearance of HCV infection which occurs in individuals with chronic hepatitis $\mathrm{C}$, after receipt of successful antiviral treatment. All of these individuals are considered to have completely recovered from $\mathrm{HCV}$ infection and to have been immunized against at least the corresponding HCV strain. On the other hand, there are healthy individuals with normal ALT or SGPT levels who test positive for anti - HCV antibodies in the absence of serum HCV RNA and who have no history of acute or chronic liver disease. This situation could reflect an immunological response to an unapparent exposure to $\mathrm{HCV}$ without clinical consequences, rather than a clearance of a HCV infection [26].

In patients with risk factors for hepatitis $\mathrm{C}$ or an abnormal SGPT, the most practical method of diagnosing $\mathrm{HCV}$ infection is by obtaining a second generation enzyme linked immune sorbent assay (EIA) antibody to hepatitis C (anti - HCV). False-positive results may occur at a rate of $10-20 \%$ and are usually seen in the presence of autoimmune disease, hypergamma globulinemia and low-risk blood donors. False negative results may occur in immune suppressed patients, including people infected with the human immunodeficiency virus. In early infection, anti-HCV testing may be negative, as antibodies may not develop until 4-6 weeks after exposure. Unfortunately, a positive hepatitis $\mathrm{C}$ antibody does not distinguish acute from chronic disease or active from past infection nor is it a sign of immunity or protection. Therefore, a positive EIA anti - HCV test is a marker that hepatitis $\mathrm{C}$ may be present and it must be followed by confirmatory viral load testing.

The present study was undertaken to determine HCV viral load in nephrology unit and its correlation with the biochemical parameters . Anti -HCV antibody-positive, serum HCV RNA-negative patients who have normal ALT levels may be considered to be patients who have cleared HCV infection, either spontaneously or after successful antiviral treatment. Clearance of the virus from the peripheral blood has contributed towards absence of viral load detected by RTPCR.

The statistical analysis (determination of mean and standard deviation) performed on biochemical parameters correlated with the results published by the earlier groups [26-31]. The results of logistic regression analysis performed on biomarkers and viral load revealed that elevation of alkaline phosphates enzyme levels is a biomarker for detecting HCV infection. This finding correlated with the reports published by the other research groups [32-37].

\begin{tabular}{|l|l|l|}
\hline \multirow{2}{*}{ Serum Biomarkers } & $\begin{array}{l}\text { HCV RNA POSITIVE } \\
\mathbf{n = 3 1}\end{array}$ & $\begin{array}{l}\text { HCV RNA NEGATIVE } \\
\mathbf{n = 1 9}\end{array}$ \\
\cline { 2 - 3 } & Mean \pm Standard deviation & Mean \pm Standard deviation \\
\hline SGPT & $29.37 \pm 18.551$ & $\mathbf{2 8 . 3 2} \pm 13.469$ \\
\hline Bilirubin & $0.853 \pm 0.5026$ & $0.935 \pm 0.7557$ \\
\hline Alkaline phosphatase & $137.06 \pm 81.721$ & $218.58 \pm 177.225$ \\
\hline Total protein & $6.913 \pm 0.7535$ & $6.747 \pm 0.8650$ \\
\hline Albumin & $3.800 \pm 0.6266$ & $3.737 \pm 0.6483$ \\
\hline
\end{tabular}

Table 2: Comparative analysis of the mean and standard deviation of serum biomarkers parameters with HCV RNA positive and HCV RNA negative groups.

\begin{tabular}{|l|l|l|l|}
\hline \multirow{2}{*}{ Biochemical parameter } & \multirow{2}{*}{$\boldsymbol{P}$ value } & 95\% Confidence interval \\
\cline { 3 - 4 } & & Lower & Upper \\
\hline SGPT & $0.641(\mathrm{NS})$ & 0.962 & 1.065 \\
\hline Bilirubin & $0.358(\mathrm{NS})$ & 0.414 & 11.447 \\
\hline Alkaline phosphatase & $0.029^{\star}$ & 0.985 & 0.999 \\
\hline Total protein & $0.865(\mathrm{NS})$ & 0.378 & 3.179 \\
\hline Albumin & $0.525(\mathrm{NS})$ & 0.205 & 2.242 \\
\hline
\end{tabular}

${ }^{*} P$ value $<0.05$ statistically significant, NS: Not significant

Table 3: Logistic regression analysis - Hosmer and Lemehow test performed on biochemical parameters. 
Citation: Bagyalakshmi R, Malathi J, Prathiba K, Samson Y, Ravichandran R, et al. (2012) A Correlative Study on Hepatitis C Virus Load Determined by Real Time Polymerase Chain Reaction with Serum Biomarkers in Patients with Renal Disease. J Mol Biomark Diagn 3:123. doi:10.4172/2155-9929.1000123

The degree of HCV infection has been associated with increased viral load [38]. Alkaline phosphatase has 6 isozymes present in bone, liver, skeletal muscle, kidney, small intestine and placenta [39]. The increased alkaline phosphatase in HCV patients may be due to- HCV replication in bone marrow leading to release of the enzyme from damaged marrow cells [40,41].HCV replication and infection in kidneys leading to elevated enzyme level. Chronic HCV infection may lead to hepatic carcinoma and alkaline phosphatase level is a known biomarker for hepatic carcinoma [42].

Our study group consisted of patients with renal pathology who have malfunctioning kidneys. In the present study - SGPT, Bilirubin albumin and protein levels did not show correlation with HCV viral load. Though, SGPT bilirubin levels are more specific indicators of liver disease compared to alkaline phosphatase levels, considering the proven extrahepatic manifestations and extrahepatic replication of $\mathrm{HCV}$, alkaline phosphatase might be a better marker taking into account its presence in extrahepatic tissues affected by HCV. Moreover SGPT and bilirubin levels increase only in acute HCV but not in chronic HCV infection. Also alkaline phosphatase levels have been shown to predict relapse of HCV infection after interferon treatment. Thus, alkaline phosphates levels may be a good indicator of HCV viral load. Further studies to determine the specific alkaline phosphatase isozyme will give an insight into the source of the enzyme and the tissue affected.

Confirmatory tests for the presence of hepatitis $\mathrm{C}$ infection are those tests that determine the presence of hepatitis $\mathrm{C}$ viral particles (HCVRNA) in the blood. A positive HCV- RNA in the serum confirms the diagnosis of active hepatitis $\mathrm{C}$. This type of viral testing may be either qualitative or quantitative. Quantitative testing reports on the actual measured amount of viral particles in the serum and the viral levels are usually expressed as thousands or millions of international units. However, it has been suggested that a higher hepatitis $\mathrm{C}$ viral load is associated with a more rapid progression to advanced disease. Further investigations are needed to determine the genotype (s) prevalent in Indian population and its association with a high viral load. Determination of viral load is a reliable diagnostic test in assessing the prognosis of the patient to antiviral therapy. Hence we conclude that elevated alkaline phosphatase levels is associated with HCV infection and this finding is the first to be reported in Indian literature to the best of our knowledge.

\section{Acknowledgement}

We extend our sincere thanks to Dr Rajan Ravichandran Head Nephrology Unit, MIOT Hospital for referring the clinical specimens for the study and his able guidance in the preparation of the manuscript. We also extend our gratitude to the statistician Mr Thennarasu in helping with statistical analysis.

\section{References}

1. Beld M,Penning M, McMorrow M, Gorgels J, vanden Hoek A, et al. (1998) Different Hepatitis C Virus (HCV) RNA load profiles following seroconversion among injecting drug users without correlation with HCV genotype and serum alanine aminotransferase levels. J Clin Microbiol 36: 872-877.

2. De Mitri M, Poussin SK, Baccarini P, Pontisso P, D'Errico A, et al. (1995) HCV associated liver cancer without cirrhosis. Lancet 345: 413-415.

3. Esteban R (1993) Epidemiology of hepatitis C virus infection. J Hepato 17(Suppl) 3: S67-S71.

4. Saito I, Miyamura T, Ohbayashi A, Harada H, Katayama T, et al. (1990) Hepatitis $C$ virus infection is associated with the development of hepatocellular carcinoma. Proc Natl Acad Sci USA 87: 6547-6549.

5. Lau J, Davis YGL, Kniffen J, Qian KP, U rdea MS, et al. (1993) Significance of serum hepatitis $C$ virus RNA levels in chronic hepatitis $C$. Lancet 341:15011504.
6. Magrin S, Craxi A, Fabiano C, Marino L,Fioretino G, et al. (1996) HCV viraemia is more important than genotype as a predictor of response to interferon in Sicily (Southern Italy). J Hepatol 25:583-590.

7. Mizokami M, Orito E, Gibo Y, Suzuki K, Ohba K, et al.(1996) Genotype, serum Level of hepatitis $C$ virus RNA and liver histology as predictors of response to interferon-al pha $2 a$ therapy in Japanese patients with chronic hepatitis C. Liver 16: 23-27.

8. Nakamura $H$, Ito $H$, Ogawa $H$, Takeda A, Kanazawa $S$, et al. (1999) Initial daily interferon administration can gain more eradication of HCV RNA in patients with chronic hepatitisC especially with serum intermediate viral load. Heaptogastroenterology 46: 1131-1139.

9. Perico N, Cattareo D, Bikbov B, Renuzzi G (2009) Hepatitis C infection and chronic renal disease. Clin J Am Soc Nephrol 4: 207-220

10. Fabrizi F, Poordad FF, Martin P (2002) Hepatitis C infection and the patient with end- stage renal disease. Hepatology 36: 3-10.

11. Pawlotsky JM (1999) Diagnostic tests for hepatitis C. J Hepatol 31(Suppl 1) 71-79.

12. Gretch DR, Corey L, de la Rosa C, Carithers RL (1996) Assessment of hepatitis C viremia using molecular amplification technologies. Viral Hepatitis Rev 2 85-96.

13. Young KK, Resnick YRM, Myers TW (1993) Detection of hepatitis C virus RNA by a combined reverse-transcription-polymerase chain reaction assay. $\mathrm{J}$ Clin Microbiol 31: 882-886

14. Alter HJ, Sanchez PR, Urdea MS, Wilber JC, Lagier RJ, et al. (1995) Evaluation of branched-DNA signal amplification for the detection of hepatitis $\mathrm{C}$ virus RNA J Viral Hepatitis 2: 121-132.

15. Halfon P, Borliere M, Penanada G, Khiri H, Ouzan D, et al. (2006) Real Time $\mathrm{PCR}$ assays for HCV RNA quantitation are adequate for clinical management of patients with chronic HCV infection. J Clin Mlcrobiol 44: 2507-2511.

16. Mulligan EK, Germer JJ, Arens MQ, D'Amone KL, Bisceglie AD, et al. (2009) Detection and quantification of HCV by multicode RTx Real Time PCR targeting the HCV 3' UTR. J Clin Microbiol 47: 2635-2638.

17. Trujillo MKC, Perez IDC, Rios Ibarra CP, Ramriez -Valles EG, Rincon Sanchez AR, et al. (2011) Absolute quantitation of different geno types of HCV RNA in clinical samples by a modified Real Time PCR method. Lab Med 2011 42: 333-337.

18. Chevaliez S, Borier -Alias M, Pawlotsky J (2009) Performance of the Abbott RTPCR assay using m2000sp and m2000rt for HCV RNA quantification. J Clin Microbiol 47: 1726-1732.

19. Sabato MF, Shiffman ML, Langley MR, Wilkinson DS, Gonzalez A, et al (2007) Comparison of performance characteristics of three Real Time reverse Transcriptase PCR test systems for detection and quantitation of HCV. J Clin Microbiol 45: 2529-2536.

20. Halfon P, Bourliere M, Ouzan D, Sene D, Saadoun D, et al. (2008) Occult $\mathrm{HCV}$ infection revisited with ultrasensitive RT PCR assay. J Clin Microbiol 46: 2106-2108.

21. Laperche S, Bouchardeau F, Garnier EA, Thibault V, Roque Afnose A, et al. (2011) Interpretation of Real Time PCR results for HCV RNA when viral load is below quantification limits. J Clin Microbiol 49: 1113-1115.

22. White PA, Pan Y, Freeman AJ, Marinos G, French RA, et al. (2002) Quantification of HCV in human liver and serum samples by using light cycler reverse transcriptase PCR. J CLin Microbiol 40: 4346-4348.

23. Tuallain E, Mondain A, Ottomani L, Roudiere L, Perney P, et al. (2007) Impact of HCV genotypes on quantification of HCV RNA in serum by COBAS Ampliprep/ COBAS Taqman HCV test, Abbott Antiretroviral therapy HCV Rea Time PCR assay and versant HCV RNA assay. J Clin Microbiol 45: 3077-3081.

24. Vermeheren J, Kau A, Gatner BC, Gobez R, Zeozam S, et al.(2008) Difference between two Real Time PCR assaya and one signal amplification assay for RNA detection and quantification. J Clin Microbiol 46: 388-3891.

25. Shakil AO, Conry CC, Alter HJ, Hyashi P, Kleiner DE, et al. (1995) Voluntary blood donors with antibody to Hepatitis $C$ virus: clinical, biochemical, virological and histological features. The Hepatitis C study group. Ann Intern Med 123 330-337. 
Citation: Bagyalakshmi R, Malathi J, Prathiba K, Samson Y, Ravichandran R, et al. (2012) A Correlative Study on Hepatitis C Virus Load Determined by Real Time Polymerase Chain Reaction with Serum Biomarkers in Patients with Renal Disease. J Mol Biomark Diagn 3:123. doi:10.4172/2155-9929.1000123

26. Carnero V, Pardo M, Lopez AJM, Rodriguez IER, Bartolome J, et al. (2006) Detection of HCV in the liver of healthy, anti HCV antibody positive serum HCV RNA negative patients with norml alanine amino transferase levels. J Inf Dis 194: 53-60.

27. Berry V, Arora R, Paul P (2005) Hepatitis C clinical outcome and diagnosis. JK Sci 7: 129-132.

28. Dusheiko G, Schmilovitz -Weiss H, Brown D, McOmish F, Yap PL, et al. (2005) Hepatitis $C$ virus genotypes: An investigation of type specific differnces in geographic origin and disease. J Hepatol 19: 13-18.

29. Lopez LFX, Amprurdanes S, Forns X, Castells A, Saiz JC, et al. (1997) HCV genotypes in Spanish patients with HCV infection: relationship between genotype 1b, cirrhosis and hepatocellular carcinoma. J Heaptol 27: 959-65.

30. Verma V, Chakravarti A, Kar P (2008) Genotypic characterization of HCV and its significance in patients with chronic liver disease from North India. Diagn Microbiol Infect Dis 61: 408-414.

31. Chakravarthi A, Dogra G, Verma V, Srivastava AP (2011) Distribution pattern of HCV genotypes and its association with viral load .Ind H Med Res 133: 326331.

32. Peng YC, Hsich SC, Yang DY, Tung CF, Hu WH, et al. (2001) Experimental and clinical significanc e of anti - nuclear antibodies in HCV. J Clin Gastroenterol 33: $402-406$

33. Colombatu P, Randone A, Civirico G, Gorin GM, Dolci L, et al. (1997) HCV in patients with cryptogenic liver disease with elevated CGT and ALP serum levels. J Viral Hep 4: 55-60.
34. Shuncha ng S, Weidong C, Hong L (2009) Analysis of serum enzyme activity in HCV infection. China Trop Med 9: 656-657.

35. Wanachiwanawin $W$, Luengrojanakul $P$, Sirangkapracha $P$, Leowattana $W$, Fucharoen S, et al. (2003) Prevalence and clinical significance of HCV infection in Thai patients with thalassemia. Int J Haematol 78: 374-378.

36. Hursnain RR, Koukab G, Qayyaum M, Asim M, Khanum A, et al. (2007) Association of diabetes with $\mathrm{HCV}$ infected male and female patients along with different risk factors. Int J Agricul Biol 9: 736-740.

37. Bodl aj G, Hubmann R, Saleh K, Stojakovic T, Besenbuch G, et al (2010) Alkaline phosphatase predicts relapse in chronic HCV patients with end of treatment response. World J Gastroenterol 16: 2407-2410.

38. Bonkovsky HL, Mehra S (2001) Hepatitis C: A review. J Am Acad Dermato 44: 159-179.

39. Giannini EG, Testa R, Savarino V (2005) Liver enzyme alteration : a guide to clinician. Can Med Assoc J 172: 367-369.

40. Radkowski M, Kubicka J, Kisiel E, Cianciara J, Nowicki M, et al. (2000) Determination of active HCV and HGV / GB virus $\mathrm{C}$ replication in bone marrow in human subjects. Blood 95: 3986-3989.

41. Manzin AGA, Caniglia CML, Paolucci S, Danieli MG, Clemeti M, et al.(1994) Active HCV infection in bone marrow and peripheral blood mononuclear cells from patients with mixed cryoglobulinaemia. Clin Exp Immunol 97: 87-93.

42. Gumber SC, Chopra S (1995) Hepatitis C: A multifaceted disease: reviews of extra hepatic manifestations. Ann Intern Med 123: 615-620. 